Monika Rucińska ${ }^{1,2}$, Karolina Osowiecka ${ }^{3}$, Teresa Kocbach², Radosław Środa ${ }^{4}$, Olga Wilk ${ }^{4}$, Marta Dusza ${ }^{4}$

${ }^{1}$ Katedra Onkologii, Uniwersytet Warmińsko-Mazurski w Olsztynie

${ }^{2}$ Centrum Opieki Paliatywnej im. Jana Pawła II w Olsztynie

${ }^{3}$ Katedra Zdrowia Publicznego, Epidemiologii i Mikrobiologii, Uniwersytet Warmińsko-Mazurski w Olsztynie; Uniwersytecki

Szpital Kliniczny w Olsztynie

${ }^{4}$ Studenckie Koło Naukowe przy Katedrze Onkologii, Uniwersytet Warmińsko-Mazurski w Olsztynie

\title{
Studenci medycyny wobec informowania pacjentów o niekorzystnym rozpoznaniu i rokowaniu
}

\author{
Medical students and delivering poor prognosis \\ and bad news to patients
}

\section{Streszczenie}

Wstęp. Prawo do informacji o stanie zdrowia jest jednym z podstawowych praw pacjenta. Przekazywanie pacjentom niekorzystnych wiadomości o rozpoznaniu i rokowaniu jest trudnym zadaniem budzącym wiele emocji i problemów. Celem pracy była ocena postaw studentów medycyny wobec informowania pacjentów o niekorzystnym rozpoznaniu i rokowaniu.

Materiał i metody. Badaniem ankietowym objęto 83 studentów V i VI roku medycyny po ukończeniu zajęć z dwóch przedmiotów: onkologii i medycyny paliatywnej.

Wyniki. Wszyscy ankietowani uważają, że lekarz powinien mówić prawdę pacjentowi o niekorzystnym rozpoznaniu i rokowaniu. Wszystkie badane osoby, oprócz jednej, stwierdziły, że w przypadku poważnej choroby chciałyby poznać prawdę o rozpoznaniu i złym rokowaniu, ale część osób nie chciałaby, aby taką informację otrzymali ich bliscy w tej samej sytuacji. Większość respondentów uważa, że poznanie prawdy o rozpoznaniu i złym rokowaniu jest potrzebne i może pomóc pacjentowi. Ankietowani studenci w większości przypuszczają, że w przyszłości przekazywanie niekorzystnych wiadomości będzie dla nich trudne. Wnioski. Wydaje się, że celowe byłoby zwrócenie większej uwagi na przygotowanie studentów do przekazywania trudnych informacji pacjentom. Pomóc w tym mogłoby rozpowszechnienie schematów prowadzenia trudnych rozmów, takich jak metoda sześciu etapów przekazywania niekorzystnych informacji (SPIKES, A Six-Step Protocol for Delivering Bad News).

Palliat Med Pract 2018; 12, 4: 179-185

Słowa kluczowe: przekazywanie trudnych wiadomości, niekorzystne rokowanie, SPIKES, studenci medycyny

\section{Abstract}

Background. Obtaining information about ones health condition is one of basic rights of a patient. However, breaking bad news about diagnosis and prognosis is a difficult task causing a lot of emotions and issues. The aim of the study was to evaluate medical students' opinions on informing patients about diagnosis and poor prognosis.

\section{Adres do korespondencji:}

Monika Rucińska

Katedra Onkologii, Uniwersytet Warmińsko-Mazurski w Olsztynie

e-mail: m_rucinska@poczta.onet.pl 
Material and methods. A survey study included $835^{\text {th }}$ and $6^{\text {th }}$ year medical students who have completed courses of oncology and palliative medicine.

Results. All students stated that doctors should always give the correct information about diagnosis and poor prognosis to their patients. All participants, except for one declared that in case of severe illness they would like to know the truth about their diagnosis and prognosis, but some of them wouldn't want their family to have that information in same situation. Most of respondents believed that the truth about diagnosis and bad prognosis is necessary and could even help patients. Surveyed students in majority admitted, that breaking bad news in future would be difficult for them.

Conclusions. It seems it would be justified to put more emphasis on preparing medical students for delivering bad news to patients. Spreading protocols of interview like A Six-Step Protocol for Delivering Bad News (SPIKES) could be helpful.

Palliat Med Pract 2018; 12, 4: 179-185

Key words: breaking bad news, poor prognosis, SPIKES, medical students

\section{Wstęp}

Zgodnie z polskim prawem istnieją jasne zasady dotyczące informowania pacjenta o jego stanie zdrowia [1-4]. Prawo do informacji o stanie zdrowia jest jednym z podstawowych praw pacjenta, które wynika głównie z szacunku do osoby, poszanowania jej godności i autonomii. Wiedza na temat swojego stanu zdrowia jest niezbędna choremu do podejmowania decyzji dotyczących leczenia, jak również życia osobistego, społecznego i zawodowego. Jednak kwestia przekazywania wiadomości pacjentom o rozpoznaniu i rokowaniu, szczególnie niekorzystnych, budzi wiele emocji i problemów. Ten aspekt komunikacji pomiędzy lekarzem a pacjentem jest szczególnie trudny, głównie dla pacjenta, dla którego informacje o chorobie zmieniają, niekiedy całkowicie, sytuację życiową, stanowią o zagrożeniu biologicznym, społecznym i w sferze psychologicznej. Jest to sytuacja również trudna dla lekarza, który musi zmierzyć się z różnymi, nierzadko bardzo silnymi emocjami pacjenta, z własnymi lękami i słabościami. Lekarze nie zawsze znają obowiązujące przepisy, obawiają się przekazywać niekorzystne wiadomości, nie biorą odpowiedzialności lub nie potrafią przekazywać niepomyślnych informacji chorym $[5,6]$. Lekarze obawiają się reakcji pacjenta, ponieważ często nie wiedzą jak sobie z nią poradzić. Nie informując chorego, ukrywając niekorzystne wiadomości o rozpoznaniu i rokowaniu, bądź przekazując je wyłącznie rodzinie bez uzgodnienia tego z pacjentem, lekarze często powołują się na dobro i chęć ochrony chorego, nieodbieranie nadziei i chęci do życia [6]. Ponadto, lekarze nie przekazują złych wiadomości, bo obawiają się odrzucenia przez chorego [6]. Szczególnie trudne zadanie mają lekarze onkolodzy, którzy bardzo często stają wobec konieczności przekazania pacjentowi in- formacji o nieuleczalnej chorobie [6-9]. W świadomości społecznej rozpoznanie choroby nowotworowej najczęściej kojarzone jest z cierpieniem i śmiercią. Informowanie pacjenta o nieuleczalnej chorobie jest trudne także dlatego, że lekarz uświadamia sobie ograniczenia medycyny, a także własną śmiertelność [6]. W ostatnich latach obserwuje się zmianę postaw odnośnie do mówienia prawdy pacjentom i konieczności rzetelnego informowania chorego o niepomyślnym rozpoznaniu i rokowaniu [10-12]. Przekazanie informacji o niekorzystnym rokowaniu jest niezwykle trudnym i często powodującym stres zadaniem, do którego niezbędne jest posiadanie pewnej wiedzy i umiejętności [5]. Zagadnieniu temu poświęcane jest nadal zbyt mało miejsca w nauczaniu przed- i podyplomowym, a lekarze zazwyczaj sami wypracowują własne metody informowania, niejednokrotnie stosując zasadę prób i błędów [5, 9, 13]. Wydaje się, że konieczne jest rozpoczynanie edukacji, kształtowanie właściwych postaw i ćwiczenie umiejętności rozmowy z pacjentem i przekazywania niekorzystnych wiadomości od początku studiów medycznych. Celem pracy była ocena postaw studentów medycyny wobec informowania pacjentów o niekorzystnym rozpoznaniu i rokowaniu.

\section{Materiał i metody}

Badaniem ankietowym przeprowadzonym w maju 2018 roku objęto 83 studentów (31 mężczyzn i 50 kobiet, w 2 przypadkach brak danych) V i VI roku medycyny (tab. 1). Wszyscy studenci odbyli zajęcia i zaliczyli z oceną pozytywną przedmioty: onkologia i medycyna paliatywna (obydwa realizowane na $\mathrm{V}$ roku studiów). Udział w badaniu był dobrowolny i anonimowy. Do obliczeń statystycznych użyto testu chi ${ }^{2}$, za statystycznie istotną uznawano wartość $\mathrm{p}$ poniżej 0,05. 


\section{Wyniki}

Wszyscy ankietowani na pytanie, czy lekarz powinien mówić prawdę pacjentowi o rozpoznaniu i złym rokowaniu, odpowiedzieli twierdząco (tab. 2). Większość badanych (83\%) uważała, że możliwe jest przekazanie informacji o niekorzystnym rokowaniu w taki sposób, aby nie pozbawiać pacjenta nadziei. Ponad 2/5 badanych studentów (43\%) sądziła, że lekarz może wzbudzić w pacjencie nadzieję na lepsze rokowanie, niż jest w rzeczywistości. Oprócz jednej osoby, wszyscy badani (99\%) stwierdzili, że w przypadku poważnej choroby chcieliby poznać prawdę o niekorzystnym rozpoznaniu i rokowaniu. Jednak na pytanie: „czy w przypadku zachorowania na ciężką chorobę kogoś z Twoich bliskich chciałbyś, aby poznał on prawdę o rozpoznaniu i złym rokowaniu?", 7 ankietowanych studentów (8\%) odpowiedziało nie/raczej nie. Spośród badanych $17 \%$ respondentów uważało, że lekarz może odstąpić od informowania chorego o rozpoznaniu i rokowaniu na prośbę rodziny pacjenta, „zdecydowanie nie” na to pytanie odpowiedziało 28 studentów (34\%).

Na pytanie: „czy w przypadku zachorowania na ciężką chorobę kogoś z Twoich bliskich chciałbyś, aby poznał on prawdę, jak długo będzie żył?", 78\% badanych studentów odpowiedziało twierdząco. Natomiast na analogiczne pytanie dotyczące własnej osoby $86 \%$ ankietowanych odpowiedziało „raczej tak/zdecydowanie tak". Zdecydowanie nie chciałoby posiadać takiej wiedzy 5 studentów (6\%), tyle samo nie chciałoby, aby ich bliscy uzyskali taką wiedzę.

Tabela 1. Charakterystyka badanej grupy studentów medycyny

\begin{tabular}{|c|c|c|}
\hline Paramentry & $\begin{array}{c}\text { Liczba } \\
\text { osób }\end{array}$ & Odsetek \\
\hline \multicolumn{3}{|l|}{ Płeć } \\
\hline Mężczyźni & 31 & 37 \\
\hline Kobiety & 50 & 60 \\
\hline \multicolumn{3}{|l|}{ Miejsce zamieszkania } \\
\hline Wieś & 10 & 12 \\
\hline Miasto $\leq 100$ tys. mieszkańców & 20 & 24 \\
\hline Miasto $<100$ tys. mieszkańców & 51 & 61 \\
\hline \multicolumn{3}{|l|}{ Któreś z rodziców jest lekarzem } \\
\hline Tak & 15 & 18 \\
\hline Nie & 66 & 80 \\
\hline \multicolumn{3}{|l|}{ Ktoś z bliskich chorował na nowotwór } \\
\hline Tak & 48 & 58 \\
\hline Nie & 33 & 40 \\
\hline
\end{tabular}

Wszyscy oprócz 5 respondentów (93\%) uważali, że poznanie prawdy o rozpoznaniu i złym rokowaniu jest potrzebne i może pomóc pacjentowi.

Spośród ankietowanych $80 \%$ studentów uważało, że w przyszłości przekazywanie złych wiadomości pacjentom będzie sprawiało im trudności, przy czym jedna osoba (1\%) stwierdziła, że zdecydowanie nie będzie to stanowiło problemu.

Nie zaobserwowano różnic zależnych od płci i wieku w odpowiedziach na wszystkie pytania oprócz jednego - kobiety częściej niż mężczyźni obawiały się, że przekazywanie złych wiadomości pacjentom będzie w przyszłości sprawiało im trudność $(p=0,049)$. Studenci mieszkający w dużym mieście ( $>100$ tys. mieszkańców) częściej deklarowali chęć poznania prawdy o pozostałej długości życia zarówno w przypadku własnej choroby, jak i choroby bliskich $(p=0,02)$, natomiast dzieci lekarzy rzadziej chciałyby poznać te informacje ( $p=0,0004)$. Fakt, że ktoś bliski chorował na nowotwór nie wpływał na udzielane odpowiedzi na poszczególne pytania.

\section{Dyskusja}

Zgodnie z polskim prawem pacjent ma prawo do informacji o stanie zdrowia, a lekarz ma obowiązek jej udzielania. Prawo pacjenta wynika z Ustawy z dnia 6 listopada 2008 roku o Prawach Pacjenta i Rzeczniku Praw Pacjenta Rozdział 3. Art. 9. Ust. 2., według której pacjent ma „prawo do uzyskania od lekarza przystępnej informacji o stanie zdrowia pacjenta, rozpoznaniu, proponowanych oraz możliwych metodach diagnostycznych i leczniczych, dających się przewidzieć następstwach ich zastosowania albo zaniechania, wynikach leczenia oraz rokowaniu" [4]. Ustawa o zawodach lekarza i lekarza dentysty z 5 grudnia 1996 roku z późniejszymi zmianami w art. 31. pkt. 1 stwierdza, że „lekarz ma obowiązek udzielać pacjentowi lub jego ustawowemu przedstawicielowi przystępnej informacji o jego stanie zdrowia, rozpoznaniu, proponowanych oraz możliwych metodach diagnostycznych, leczniczych, dających się przewidzieć następstwach ich zastosowania albo zaniechania, wynikach leczenia oraz rokowaniu" [1]. Kodeks Etyki Lekarskiej z dnia 2 stycznia 2004 roku w art. 17. nakłada na lekarza obowiązek informowania pacjenta z „taktem i ostrożnością" [2].

Ankietowanych studentów podczas zajęć z onkologii i medycyny paliatywnej zapoznano z powyższymi normami prawnymi. Zgodnie z przekazaną wiedzą, wszyscy badani studenci uważali, że lekarz powinien mówić prawdę pacjentowi o rozpoznaniu i złym rokowaniu. W podobnym badaniu opublikowanym w 2013 roku zdecydowana większość, ale nie wszyscy 
Tabela 2. Wyniki ankiety

\begin{tabular}{|c|c|c|c|c|}
\hline & $\begin{array}{l}\text { Zdecydowanie } \\
\text { tak } \\
\text { n (\%) }\end{array}$ & $\begin{array}{c}\text { Raczej } \\
\text { tak } \\
\text { n (\%) }\end{array}$ & $\begin{array}{l}\text { Raczej } \\
\text { nie } \\
\text { n (\%) }\end{array}$ & $\begin{array}{l}\text { Zdecydowanie } \\
\text { nie } \\
\text { n (\%) }\end{array}$ \\
\hline $\begin{array}{l}\text { Czy lekarz powinien mówić pacjentowi prawdę o rozpo- } \\
\text { znaniu i złym rokowaniu? }\end{array}$ & 48 (58\%) & 35 (42\%) & 0 & 0 \\
\hline $\begin{array}{l}\text { Czy Twoim zdaniem możliwe jest takie przekazanie in- } \\
\text { formacji o bardzo złym rokowaniu, aby nie pozbawić } \\
\text { pacjenta nadziei? }\end{array}$ & $29(35 \%$ & $40(48 \%)$ & $14(17 \%)$ & 0 \\
\hline $\begin{array}{l}\text { Czy uważasz, że lekarz może odstąpić od informowania } \\
\text { chorego o rozpoznaniu i złym rokowaniu na prośbę ro- } \\
\text { dziny pacjenta? }\end{array}$ & $4(5 \%)$ & $10(12 \%)$ & 41 (49\%) & 28 (34\%) \\
\hline $\begin{array}{l}\text { Czy myślisz, że poznanie prawdy o rozpoznaniu i złym } \\
\text { rokowaniu pomaga w czymś pacjentowi? }\end{array}$ & 27 (33\%) & $50(61 \%)$ & $5(6 \%)$ & 0 \\
\hline $\begin{array}{l}\text { Czy sądzisz, że lekarz może wzbudzać w pacjencie nadzieję } \\
\text { na lepsze rokowanie, niż to jest w rzeczywistości? }\end{array}$ & 9 (11\%) & $27(32 \%)$ & 32 (39\%) & 15 (18\%) \\
\hline $\begin{array}{l}\text { Czy w przypadku zachorowania na ciężką chorobę chciał- } \\
\text { byś poznać prawdę o rozpoznaniu i złym rokowaniu? }\end{array}$ & $63(76 \%)$ & $19(23 \%)$ & $1(1 \%)$ & 0 \\
\hline $\begin{array}{l}\text { Czy w przypadku zachorowania na ciężką chorobę kogoś } \\
\text { z Twoich bliskich chciałbyś, aby poznał on prawdę o roz- } \\
\text { poznaniu i złym rokowaniu? }\end{array}$ & 27 (33\%) & 49 (59\%) & $5(6 \%)$ & $2(2 \%)$ \\
\hline $\begin{array}{l}\text { Czy w przypadku zachorowania na ciężką chorobę chciał- } \\
\text { byś wiedzieć jak długo będziesz żył? }\end{array}$ & $39(48 \%)$ & 32 (39\%) & $6(7 \%)$ & $5(6 \%)$ \\
\hline $\begin{array}{l}\text { Czy w przypadku zachorowania na ciężką chorobę kogoś } \\
\text { z Twoich bliskich chciałbyś, aby poznał on prawdę o tym } \\
\text { jak długo będzie żył? }\end{array}$ & 15 (18\%) & $50(60 \%)$ & 13 (16\%) & $5(6 \%)$ \\
\hline $\begin{array}{l}\text { Czy uważasz, że przekazywanie złych wiadomości o roz- } \\
\text { poznaniu i rokowaniu Twoim przyszłym pacjentom będzie } \\
\text { sprawiało Ci trudności? }\end{array}$ & $22(27 \%)$ & 44 (53\%) & $16(19 \%)$ & $1(1 \%)$ \\
\hline
\end{tabular}

studenci VI roku medycyny (93\%) uznali, że pacjenci powinni być informowani o niekorzystnym rokowaniu (pytanie obejmowało również informację o zbliżającej się śmierci) [14]. W niniejszej analizie $83 \%$ badanych sądziło, że możliwe jest przekazanie informacji o bardzo złym rokowaniu, tak aby nie pozbawiać pacjenta nadziei. Przekazywanie informacji w sposób niepozbawiający pacjenta szeroko pojętej nadziei nie zaprzecza zapisom prawnym. Nadzieja, którą można wzmocnić bądź wzbudzić w pacjencie, nie musi dotyczyć szansy na wyzdrowienie, która jest nierealna. Nadzieję można wówczas, zgodnie z prawdą, kierować na szansę wydłużenia czasu przeżycia, poprawę komfortu (jakości) życia, skuteczne leczenie objawów, zapewnienie dobrej opieki ze strony personelu medycznego i rodziny [6]. Interesujący jest jednak fakt, że blisko połowa ankietowanych sądziła, że lekarz może wzbudzić w pacjencie nadzieję na lepsze rokowanie, niż jest ono w rzeczywistości, a takie postępowanie może nie być zgodne z prawem i etyką. Powyższe postawy znacznie różnią się od postaw reprezentowanych przez lekarzy sprzed kilkunastu lat. Badanie Juczyńskiego i wsp. opublikowane w 1997 roku wykazało, że jedynie 3\% lekarzy przy niekorzystnym rokowaniu przekazałoby całą prawdę choremu, 76\% ankietowanych zrobiłoby to w sposób pozostawiający pacjentowi nadzieję, czyli informowałoby w sposób niepełny [15].

Zaskakujące jest, że pomimo poznania regulacji prawnych, $17 \%$ ankietowanych uważało, że lekarz może odstąpić od informowania chorego o rozpoznaniu i złym rokowaniu na prośbę rodziny pacjenta, połowa badanych nie była zdecydowana (odpowiedziała „raczej nie”), a 34\% studentów było zdecydowanie przeciwnych takiemu postępowaniu. Podobne dylematy studenci medycyny wyrazili w innym badaniu - 32\% badanych uznało, że złe wiadomości należy najpierw przekazać rodzinie chorego [16]. Zgodnie z Ustawą o prawach pacjenta i Rzeczniku Praw Pacjenta Rozdział 3. Art. 9. Ust. 4. oraz Ustawą o zawodach lekarza i lekarza dentysty Art. 31. pkt. 3. i 4, jedynie pacjent może odmówić przyjęcia takich informacji lub lekarz może „ograniczyć informację o stanie zdrowia i o rokowaniu, jeśli według oceny lekarza przemawia za tym dobro pacjenta" - tak zwana zasada przywileju terapeutycznego [1, 4]. Jednak, zgodnie z powyższymi regulacjami, lekarz na prośbę pacjenta ma obowiązek udzielić informacji. 
Bycie informowanym jest uprawnieniem pacjenta, a nie jego obowiązkiem. Chory może nie chcieć usłyszeć informacji o swoim stanie zdrowia i o rokowaniu i w takiej sytuacji lekarz ma obowiązek przekazać jedynie informacje, które są niezbędne do podjęcia przez pacjenta decyzji odnośnie do leczenia. Wszyscy ankietowani studenci, oprócz jednego, odpowiedzieli, że w przypadku ciężkiej choroby chcieliby być poinformowani o rozpoznaniu i złym rokowaniu. Postawionych w powyższej sytuacji $86 \%$ studentów chciałoby wiedzieć jak długo będą żyć, 5 studentów (6\%) zdecydowanie nie chciałoby takiej informacji uzyskać. W badaniach opublikowanych w 2003 roku, przeprowadzonych wśród studentów V i VI roku Wydziału Lekarskiego Akademii Medycznej w Białymstoku odpowiednio $77 \%$ i $83 \%$ ankietowanych stwierdziło, że w przypadku nieuleczalnej choroby chciałoby znać prawdę o stanie zdrowia [17]. Podobny odsetek (84\% ankietowanych) studentów III roku Wydziału Lekarskiego i Oddziału Stomatologii Akademii Medycznej w Poznaniu chciałoby znać rozpoznanie i rokowanie w pełnym zakresie [16]. Podobnie, $86 \%$ biorących udział w badaniu opublikowanym w 2013 roku chciatoby dowiedzieć się o nadchodzącej śmierci [14].

Na pytania dotyczące bliskich osób studenci deklarowali nieco odmienne postawy. Spośród ankietowanych $8 \%$ respondentów odpowiedziało, że nie chciałoby, aby ich bliscy zostali poinformowani o złym rokowaniu, 22\% badanych studentów nie chciałoby, aby ich bliscy uzyskali informację o przewidywanej długości życia. Taka sytuacja może wynikać z głęboko zakorzenionych postaw nakazujących ochraniać bliskich, nawet wbrew prawu. Możliwe, że nie wszyscy w ten sam sposób rozumieją autonomię jednostki i prawo do stanowienia o sobie. $Z$ jednej strony ankietowani studenci zgadzali się z tezą, że prawdziwe informacje mogą pomóc pacjentom, $z$ drugiej odmówiliby ich swoim bliskim. Prawda o stanie zdrowia i rokowaniu pozwala choremu na decydowanie o postępowaniu, podjęciu bądź zaniechaniu często uciążliwej terapii, rozwiązanie istotnych spraw, odbycie spotkań, przeprowadzenie ważnych rozmów, sporządzenie testamentu czy ewentualną realizację marzeń.

Ankietowani studenci byli zdrowi, podobnie jak ich bliscy. Wśród zdrowych mieszkańców województwa podlaskiego $78 \%$ ankietowanych deklarowało chęć poznania prawdy w sytuacji nieuleczalnej choroby [17]. Powstaje pytanie, jak do powyższych zagadnień odnoszą się chorzy. Spośród badanych 73\% pacjentów Hospicjum Domowego w Białymstoku chciało znać całą prawdę o swoim stanie zdrowia [17]. Wśród pacjentów Hospicjum w Kowarach 85\% ankietowanych twierdziło, że człowiek powinien znać rozpoznanie nieuleczalnej choroby, a $70 \%$ uznało, że powinien wiedzieć o zbliżającej się śmierci [18]. W badaniu Jenkinsa i wsp. 95\% ankietowanych pacjentów chciałoby znać rokowanie, a 98\% chciałoby wiedzieć, czy chorują na nowotwór [19]. W przeglądzie literatury dotyczącej przekazywania złych wiadomości dokonanym przez Fujimori i Uchitomi wykazano, że zdecydowana większość chorych na nowotwory chce znać prawdę o rozpoznaniu, rokowaniu i postępie choroby [20]. Cassileth i wsp. w 1980 roku przedstawili wiarygodne dane świadczące, że pacjenci chcą być informowani o rozpoznaniu i złym rokowaniu oraz chcą brać udział w decyzjach dotyczących leczenia [21]. Okazuje się jednak, że wielu chorych, także w Polsce, nie otrzymuje wyczerpujących informacji na temat stanu zdrowia. W badaniu z udziałem 250 pacjentów Wojewódzkiego Specjalistycznego Szpitala w Łodzi, wykazano, że jedynie $32 \%$ chorych czuło się odpowiednio poinformowanych o stanie zdrowia [22]. Podobnie w grupie 40 pacjentów Hospicjum w Kowarach jedynie 30\% chorych otrzymało pełną informację o chorobie i stanie zdrowia [18].

Przekazywanie pacjentowi informacji o stanie zdrowia i rokowaniu wymaga umiejętności prawidłowej komunikacji z pacjentem i odpowiedniej wiedzy psychologicznej [5, 6]. Chociaż nie ma idealnego sposobu przekazywania pacjentowi niepomyślnych wiadomości o stanie zdrowia, istnieją przydatne schematy: metoda sześciu etapów przekazywania niekorzystnych informacji (SPIKES, A Six-Step Protocol for Delivering Bad News) [9, 23], ABCDE [24, 25], BREAKS [26] czy metoda 10 stopni [27]. Wszystkie wymienione metody oparto na podstawowych zasadach:

- przygotowanie się do przekazania informacji;

- przygotowanie odpowiedniego miejsca i okoliczności;

- ocena aktualnej wiedzy pacjenta, jego oczekiwań i chęci przyjęcia informacji;

- przekazanie informacji w sposób zrozumiały dla pacjenta;

- empatyczne zrozumienie reakcji pacjenta;

- podsumowanie rozmowy i wytyczenie planu dalszego postępowania [28].

Szczególnie przydatny jest schemat SPIKES. Zasady tej metody obejmują nawiązanie dobrego kontaktu $z$ chorym na poziomie racjonalnym i emocjonalnym, przekazanie rzetelnej informacji o chorobie, wsparcie emocjonalne pacjenta $i$ ustalenie $z$ chorym strategii postępowania/leczenia. Schemat SPIKES zakłada stopniowe przygotowanie pacjenta do przyjęcia niekorzystnej informacji, stopniowe przekazywanie informacji choremu i wspólne ustalenie dalszego postępowania. Schemat SPIKES obejmuje 6 etapów niezbędnych w procesie przekazywania niekorzystnych wiadomości. Pierwszy to właściwe nawiązanie relacji 
z pacjentem, stworzenie atmosfery szacunku i partnerstwa, odpowiednie miejsce i czas na rozmowę, odpowiednia postawa osoby informującej, używanie zrozumiałego dla pacjenta słownictwa, obecność bliskiej osoby (Setting up the interview). Następny etap stanowi ocena wiedzy pacjenta na temat choroby, stanu zdrowia i rokowania, jak chory postrzega swoją sytuację i jakie ma oczekiwania (Perception). Dalej należy usłyszeć/odebrać od pacjenta sygnał, czy i co chce wiedzieć, czy chce otrzymać informacje, które lekarz chce mu przekazać i jakie jest zapotrzebowanie chorego względem szczegółów przekazywanych informacji (Invitation/information). Czwarty etap stanowi poprzedzone tak zwanym „strzałem ostrzegawczym”, przystępne, w zrozumiałych dla pacjenta słowach, przekazanie informacji, najlepiej w „małych porcjach”, z pozostawieniem choremu nadziei (Knowledge).

Po przekazaniu niekorzystnych wiadomości należy być przygotowanym na przyjęcie emocji pacjenta i zareagować milczeniem, gestem bądź odpowiednimi słowami, a także zapewnić choremu odpowiednią ilość czasu i możliwość zadawania pytań (Emotions and empathy). Na koniec przychodzi czas na przedstawienie pacjentowi możliwości leczenia/postępowania, na ustalenie wspólnie z chorym dalszego postępowania (Strategy and summary). Schemat SPIKES jest częściowo oparty na danych empirycznych i został zweryfikowany pozytywnie w nauczaniu studentów kanadyjskich [23, 29]. Balle i wsp opisali warsztaty dla lekarzy przeprowadzone w Stanach Zjednoczonych na podstawie schematu SPIKES - 80\% uczestników uznało przydatność metody SPIKES w pracy z pacjentem, ponadto $25-60 \%$ informacji dotyczących przekazywania złych informacji było dla lekarzy nowych i nieznanych [30]. W ankiecie przeprowadzonej na koniec interaktywnego sympozjum ASCO na temat przekazywania niekorzystnych wiadomości z zastosowaniem schematu SPIKES, 95\% uczestników uznało metodę za praktyczną i przydatną w codziennej pracy z chorymi [23, 31]. Schemat SPIKES jest znany także w Polsce, dotychczas jednak nie upowszechniono go w nauczaniu przed-i podyplomowym lekarzy, chociaż podejmowano takie próby [32]. Mimo że metoda nie uwzględnia różnic kulturowych, to jest zgodna z obowiązującymi w Polsce przepisami prawa i zaleceniami polskich ekspertów psychoonkologii [6, $8,33,34]$. Większość ankietowanych uważa, że przekazywanie niekorzystnych wiadomości będzie sprawiało trudności, dlatego ćwiczenie schematu rozmowy może być bardzo przydatne.

\section{Wnioski}

Pacjent ma prawo do informacji o stanie zdrowia i rokowaniu, także jeżeli jest ono niepomyślne, a lekarz ma obowiązek takich informacji udzielić. Większość badanych studentów medycyny zgadza się z powyższym stwierdzeniem i uważa, że poznanie prawdy jest potrzebne pacjentowi i może korzystnie wpłynąć na stan chorego. Ankietowani studenci przewidują, że w przyszłości przekazywanie niekorzystnych wiadomości będzie dla nich trudne. Zasadne byłoby lepsze przygotowanie studentów i młodych lekarzy do trudnych rozmów z pacjentami, na przykład poprzez rozpowszechnienie schematów, takich jak SPIKES, wprowadzenie do programu nauczania zajęć z psychologiem i/lub psychoonkologiem, ćwiczenie umiejętności komunikacji z chorymi i rodzinami w formie warsztatów. Zastosowanie schematu SPIKES prawdopodobnie ułatwiałoby lekarzom przekazywanie niekorzystnych wiadomości, a pacjentom ich przyjęcie.

\section{Piśmiennictwo}

1. Ustawa o zawodach lekarza i lekarza dentysty z dnia 5 grudnia 1996 r. Art. 31.

2. Kodeks Etyki Lekarskiej $z$ dnia 2 stycznia 2004 r. Art. 13, 15, 16, 17, 21.

3. Karta Praw Pacjenta z dnia 11 grudnia 1998 r. Pkt. III.

4. Ustawa o prawach pacjenta i Rzeczniku Praw Pacjenta $z$ dnia 6 listopada 2008 r. Art. 9, 10, 11, 12.

5. Semczuk-Dembek K, Zięzio M. Dylematy dotyczące przekazywania informacji o chorobie nowotworowej. Nowa Med. 2006; 1: 9-12.

6. Świrydowicz T. Psychologiczne aspekty przekazywania niepomyślnych informacji o rozpoznaniu choroby i prognozie. Nowa Med. 2000; 97: 74-78.

7. Siedlecki P. Dlaczego należy mówić prawdę? Nowotwory. 1996; 46: 231-234.

8. De Walden-Gałuszko K. U kresu. Opieka psychopaliatywna, czyli jak pomóc choremu, rodzinie i personelowi medycznemu środkami psychologicznymi. Wydawnictwo Medyczne MAKmed, Gdańsk 2000.

9. Buckman R. Breaking bad news: the S-P-I-K-E-S strategy. Community Oncology. 2005; 2(2): 138-142, doi: 10.1016/s1548-5315(11)70867-1.

10. Jokiel M. Zmiany w opinii o informowaniu pacjentów o rozpoznaniu choroby nowotworowej w latach 1976, 1986 i 1990. Nowotwory. 1996; 46: 235-240.

11. Sepioło A. Problemy przekazywania niepomyślnych informacji pacjentom z chorobą nowotworową w Polsce i na świecie. Psychoonkologia. 1998; 2: 69-73.

12. Kubler-Ross E. Rozmowy o śmierci i umieraniu. Instytut Wydawniczy PAX, Warszawa 1979.

13. Colletti L, Gruppen L, Barclay M, et al. Teaching students to break bad news. Am J Surg. 2001; 182(1): 20-23, indexed in Pubmed: 11532409.

14. Ciałkowska-Rysz A, Dzierżanowski T. Personal fear of death affects the proper process of breaking bad news. Arch Med Sci. 2013; 9(1): 127-131, doi: 10.5114/aoms.2013.33353, indexed in Pubmed: 23515271.

15. Juczyński Z, Szamburska J, Czechowicz E. Informowanie o chorobie nowotworowej w opinii i w praktyce lekarskiej. Nowotwory. 1997; 47: 43-57.

16. Leppert W, tuczak J, Góralski P. Wybrane problemy opieki paliatywnej i eutanazji w opiniach lekarzy i studentów medycyny. Pol Med Paliat. 2005; 4: 67-76.

17. Matejuk A, Mikołajczyk E, Lewko A, et al. Opieka paliatywna czy eutanazja - postrzeganie problemu przez 
pacjentów, lekarzy, studentów medycyny i mieszkańców województwa podlaskiego. Onkol Pol. 2003; 6: 29-33.

18. Mess E, Kopytek B, Lisowska A, et al. Potrzeba informowania chorego w stanie terminalnym. Onkol Pol. 2007 10: 185-189.

19. Jenkins V, Fallowfield L, Saul J. Information needs of patients with cancer: results from a large study in UK cancer centres. Br J Cancer. 2001; 84(1): 48-51, doi: 10.1054/bjoc.2000.1573, indexed in Pubmed: 11139312.

20. Fujimori $M$, Uchitomi Y. Preferences of cancer patients regarding communication of bad news: a systematic literature review. Jpn J Clin Oncol. 2009; 39(4): 201-216, doi: 10.1093/jjco/hyn159, indexed in Pubmed: 19190099.

21. Cassileth BR, Zupkis RV, Sutton-Smith K, et al. Information and participation preferences among cancer patients. Ann Intern Med. 1980; 92(6): 832-836, indexed in Pubmed: 7387025.

22. Wroński K, Cywiński J, Depta A, et al. Czy pacjenci są dobrze informowani o stanie swojego zdrowia przez lekarzy? Wsp Onkol. 2008; 12: 234-239.

23. Baile WF, Buckman R, Lenzi R, et al. SPIKES-A six-step protocol for delivering bad news: application to the patient with cancer. Oncologist. 2000; 5(4): 302-311, indexed in Pubmed: 10964998.

24. Rabow MW, McPhee SJ. Beyond breaking bad news: how to help patients who suffer. West J Med. 1999; 171(4): 260-263, indexed in Pubmed: 10578682.

25. VandeKieft GK. Breaking bad news. Am Fam Physician. 2001; 64(12): 1975-1978, indexed in Pubmed: 11775763.
26. Narayanan V, Bista B, Koshy C. ,BREAKS' Protocol for Breaking Bad News. Indian J Palliat Care. 2010; 16(2): 61-65, doi: 10.4103/0973-1075.68401, indexed in Pubmed: 21811349.

27. Kaye P. Breaking bad news: A 10 step approach. Northampton: EPL Publications 1996.

28. Abdul Hafidz MI, Zainudin LD. Breaking Bad News: An essential skill for doctors. Med J Malaysia. 2016; 71(1): 26-27, indexed in Pubmed: 27130740.

29. Buckman R. Breaking bad news: a six-step protocol. In: Buckman R, editor. How to break bad news. A guide for health care professionals. Baltimore: Johns Hopkins University Press 1992.

30. Baile WF, Kudelka AP, Beale EA, et al. Communication skills training in oncology. Description and preliminary outcomes of workshops on breaking bad news and managing patient reactions to illness. Cancer. 1999; 86(5): 887-897, indexed in Pubmed: 10463990.

31. Lenzi R, Buckman R, Glober G, et al. The Difficult Task of Breaking Bad News: Oncologist's Attitudes, Practices and Challenges. Proc Am Soc Clin Oncol. 2000: abstract 2353.

32. Jarosz M. Przekazywanie niepomyślnych informacji w praktyce klinicznej. Onkol Prak Klin. 2013; 9: 225-229.

33. Łuczak J. Lekarz wobec umierającego. W: Wybrane problemy deontologii lekarskiej. . In: Szulc R. ed. Wybrane problemy deontologii lekarskiej. Wydawnictwo Uczelniane Akademii Medycznej im. Karola Marcinkowskiego w Poznaniu, Poznań 1999.

34. Grajcarek A. (red.) Sztuka rozmowy z chorym. Wydawnictwo Ad vocem, Kraków 2001 